\title{
MODEL PEMBERIAN PERINGKAT KINERJA PERUSAHAAN: STUDI PADA PERUSAHAAN ASURANSI JIWA DI INDONESIA
}

\author{
Novita Ratna Satiti ${ }^{1}$ \\ Fakultas Ekonomi \& Bisnis Universitas, Muhammadiyah Malang, Indonesia ${ }^{I}$
}

\begin{abstract}
Abstrak
The purpose of this study is to provide an alternative rating company based on analysis on Profitability, RBC and Premium Expenses which are the main keys to the financial performance of Insurance Companies. This research uses the Fuzzy Tools Box approach from Matlab to see different assessment patterns. Data is collected using the documentation method of Financial Statements of Insurance Companies listed on the IDX in the last five years. The research subjects were as many as 10 insurance companies that met the criteria in Indonesia. The results showed that the first dominant insurance rating in taking insurance decisions was Lippo General Insurance, second Indonesian Reinsurance Insurance, third Multi Artha Guna insurance, fourth Ramayana insurance, fifth Harta Amana Pratama insurance, six Mitra Maparya insurance, seventh Jaya insurance Tania, the eight insurers of Bina Dana Arta, the ninth Dayin Mitra insurance, and the last rank of Bintang insurance which refers to the standard level of financial health of insurance companies. This study implies that the proposed ranking is a simpler and easier ranking alternative, but still has different benefits for decision makers.
\end{abstract}

Kata Kunci: Company ranking; fuzzy logic; insurance companies

\begin{abstract}
Abstrak
Tujuan penelitian ini adalah untuk menyediakan alternatif pemeringkatan perusahaan berdasarkan analisis pada Profitabilitas, RBC dan Beban Premi yang merupakan kunci utama kinerja keuangan Perusahaan Asuransi. Penelitian inimenggunakan pendekatan Fuzzy Tools Box dari Matlab untuk melihat pola penilaian yang berbeda. Data dikumpulkan dengan menggunakan metode dokumentasi Laporan Keuangan Perusahaan Asuransi yang terdaftar di BEI dalam lima tahun terakhir. Subjek penelitian adalah sebanyak 10 perusahaan asuransi yang memenuhi kriteriayang ada di Indonesia. Hasil menunjukkan bahwa pemeringkatan asuransi peringkat pertama yang paling dominan dalam mengambil keputusan asuransi adalah asuransi Lippo General Insurance, kedua asuransi Maskapai Reasuransi Indonesia, ketiga Asuransi Multi Artha Guna, keempat asuransi Ramayana, kelima asuransi Harta Amana Pratama, keenam asuransi Mitra Maparya, ketujuh asuransi Jaya Tania, kedelapan asuransi Bina Dana Arta, kesembilan asuransi Dayin Mitra, dan peringkat terakhir asuransi Bintang yang mengacu pada standard tingkat kesehatan keuangan perusahaan asuransi. Penelitian ini memberikan implikasi bahwa pemeringkatan yang diajukan merupakan alternatif pemeringkatan yang lebih sederhana dan mudah, namun tetap memiliki manfaat yang berbeda bagi para pengambil keputusan.
\end{abstract}

Kata Kunci: Ranking perusahaan; fuzzy logic; perusahaan asuransi

\section{Pendahuluan}

Setiap tahun, terdapat tiga majalah bisnis di Indonesia yang mengumumkan peringkat asuransi dengan versi yang berbeda-beda, meski dengan sumber analisis pemeringkatan yang serupa yaitu laporan keuangan yang dipublikasikan oleh Perusahaan-perusahaan Asuransi di Indonesia. Perbedaan tersebut berasal dari metode analisis, klasifikasi dan alat/ kriteria analisis. Ketiga majalah tersebut sepakat, peer group berdasarkan ukuran perusahaan, namun kriteria ukuran perusahaan berbeda. Media Asuransi (MA) mengklasifikasikan berdasarkan ekuitas. Sedangkan pengelompokan oleh Majalah Info Bank (IB) berdasakan premi bruto. Sementara itu, Majalah Investor (MI) memilih aset untuk menentukan besarkecilnya perusahaan. Bulan Juli 2016, tiga majalah di bidang bisnis dan keuangan menerbitkan laporan utama yang mengumumkan peringkat perusahaan asuransi. Yaitu majalah Media Asuransi (MA) mengumumkan "27 Best Insurance 2016". Sedangkan di bulan yang sama majalah Info Bank (IB) dan Majalah Investor (MI) masing-masing menurunkan laporan utama dengan judul "Rating 120 Asuransi Versi Info Bank 2016" dan "20 Best Insurance Companies".

Secara toeri kriteria penilaian bergantung pula dari besaran industri. Kelompok industri asuransi umum, asuransi jiwa dan reasuransi tidak sama. Hal ini disebabkan oleh sifat bisnis yang tidak semuanya sama persis. MA memiliki dua belas kriteria penilaian pertumbuhan yaitu; pendapatan premi, premi langsung, premi tak langsung, cadangan teknis, hasil underwriting, hasil investasi, dan laba di tahun 2016 hingga kriteria tingkat penyelesaian klaim, rasio investasi, total asset turn over (TATO), rasio kualitas aset, dan return on equity (ROE).

\footnotetext{
${ }^{1}$ satiti.umm@gmail.com
} 
IB yang memiliki sepuluh kriteria. Antara lain; ukuran risk based capital (RBC), likuiditas, rasio dana jaminan terhadap cadangan teknis, rasio aktiva tetap terhadap modal sendiri, perubahan premi bruto, dan rasio pendapatan premi neto terhadap modal sendiri, hingga rasio beban klaim neto terhadap pendapatan premi neto dan rasio laba terhadap modal sendiri. MI memakai empat belas kriteria yang didominasi tujuh kriteria pertumbuhan. Yaitu; Pertumbuhan diukur selama tiga tahun pada aset, investasi, ekuitas, premi neto, hasil investasi, pendapatan dan laba bersih. Kriteria lainnya adalah pangsa pasar premi neto, TATO, ROA, RBC, dll.

Perbedaan kriteria penilaian dapat menimbulkan keraguan masyarakat sebagai pengguna jasa asuransi. Masyarakat menginginkan kepastian akan kualitas jasa asransi yang dipilih. Meskipun dalam menilai peringkat menggunakan sumber yang sama, namun karena metode analisis berbeda, maka hasilnya pun berbeda, sehingga peringkat terbaik versi sebuah majalah tidak selalu sama dengan versi majalah lain. Perusahaan yang dinilai tidak bagus oleh sebuah majalah, belum tentu perusahaannya buruk karena penilaian majalah tersebut bergantung pada kriteria penilaiannya.

Berdasarkan latar belakang tersebut, Penelitian ini bertujuan untuk: Memberikan kriteria penilaian yang sama untuk satu jenis kelompok asuransi baik asuransi Jiwa, asuransi kerugian maupun asuransi lainnya dan menilai tingkat kesehatan perusahaan dan memberikan peringkat perusahaan asuransi. Sehingga dapat disusun perumusan masalah sebagai berikut: 1) Bagaimana kriteria dalam menentukan peringkat perusahaan Asuransi? 2) Bagaimana metode yang tepat dalam memberikan peringkat pada perusahaan asuransi?

\section{Tinjauan Pustaka}

Informasi yang terstandarisasi, sederhana tetapi berkualitas akan membantu pengambil keputusan dari beragam latar belakang. Informasi berkualitas tinggi memegang peran penting sehingga harus bisa diperoleh oleh seluruh pengambil keputusan. Cara mudah dan hemat waktu yang sering digunakan pengambil keputusan dengan beragam latar belakang tersebut adalah dengan menggunakan analisis dari intermediari. Mekanisme pihak intermediari yang dianggap cukup efektif adalah dengan menggunakan signal yakni menggunakan pihak perantara untuk bisa melakukan analisis dan memberikan komentar ataupun jaminan untuk bisa selanjutnya diungkapkan kepada publik. Mekanisme ini sudah berjalan lama untuk pengambil keputusan dalam pemberian hutang yaitu dengan menggunakan debt rating, tetapi cara ini belum banyak diterapkan bagi pemegang saham dan investor ekuitas.

Salah satu sumber informasi yang dijadikan pedoman investor adalah laporan keuangan. Tujuan utama dari pelaporan keuangan adalah untuk memberikan informasi keuangan berkualitas tinggi mengenai sebuah entitas, terutama yang terkait dengan ekonomi (SAK 2012). Menghasilkan laporan keuangan yang memiliki kualitas tinggi akan memengaruhi para pemilik dan atau penyedia modal dan pemangku kepentingan lainnya (stakeholder) dalam melakukan investasi, kredit, dan alokasi sumber daya kepada entitas yang membutuhkan dan pada akhirnya akan berguna untuk pengambilan keputusan ekonomi dan meningkatkan efisiensi pasar secara keseluruhan (Scott 2012: 463).

Pemberian peringkat (rating) di Indonesia dengan membandingkan kualitas informasi Laporan Keuangan sudah dilakukan oleh beberapa instansi terpisah, seperti Annual Report Award (ARA) yang dilakukan oleh Otoritas Jasa Keuangan (OJK) yang mengangkat pembobotan berdasar pada indikator Good Corporate Governance (GCG). Majalah SWA dan FORBES juga memberikan rating pada perusahaan melalui ketahanan ekonomi dan konsistensi pemberian keuntungan. Penilaian indikator yang berbeda-beda dapat diterima karena dilihat sebagai tambahan informasi yang saling melengkapi dan tetap memenuhi peran intermediari untuk memberikan informasi keuangan berkualitas.

Penilai kualitas perusahaan di Indonesia yang menggunakan metode yang beragam, misal penilai kualitas seperti Annual Report Award (ARA) yang melihat kualitas Laporan Keuangan dengan menggunakan cara penyampaian laporan tahunan dengan berdasarkan Corporate Governanace, majalah Forbes yang memberikan peringkat kualitas Perusahaan (bukan Laporan keuangan) berdasarkan ketahanan ekonomi disaat ketidakpastian global, dan majalah SWA memiliki metode lain lagi dalam menilai kualitas sebuah perusahaan (data keuangan), yakni dengan menggunakan metode Wealth Added Index (WAI) yang menggambarkan peningkatan kekayaan pemegang saham

Perusahaan asuransi memandang Peringkat Perusahaan sebagai suatu media dalam membangun kredibilitas dan kepercayaan masyarakat. Premi didalam perusahaan asuransi merupakan suatu kesatuan yang tidak lepas dari perusahaan asuransi. Didalam perusahan asuransi, premi yang di peroleh sehubungan dengan kontrak asuransi dan reasuransi diakui sebagai pendapatan selama periode polis (kontrak) berdasarkan proporsi jumlah proteksi yang diberikan. Premi yang dibayarkan kepada pihak penanggung dari pihak tetanggung nantinya akan diakumulasikan sesuai kepada pihak tertanggung. 
Faktor-faktor yang perlu diperhatikan dalam menentukan jumlah premi: 1) Kemungkinan kerugian 2) Nilai dari setiap kerugian; 3) Biaya administrasi yang diperlukan untuk menjalankan usaha, seperti mengumpulkan premi dari setiap anggota, mengukur kerugian, membayar klaim, dan lain-lain; 4) Ambang kesalahan yang mungkin timbul saat memprediksi kerugian; 5) Faktor lainnya seperti finansial, kesehatan, dan faktor-faktor sosial.

Adapun beberapa faktor yang dijadikan indikasi adalah yang sesuai dengan keputusan mentri keuangan mengenai tingkat kesehatan perusahaan asuransi dan perusahaan reasuransi dalam KMK nomor 424/KMK.06/2003, peraturan Pemerintah republik Indonesia nomor 73 tahun 1992, majalah info bank no.340/juli 2007/vol XXIX, undang-undang nomor 2 tahun 1992 tentang peraturan usaha perasuransian:

Pertama, Rasio Rentabilitas atau disebut juga Profitabilitas menggambarakan kemampuan perusahaan mendapatkan laba melalui semua kemampuan, dan sumber yang ada seperti kegiatan penjualan, kas, modal, jumlah karyawan, jumlah cabang, dan sebagainya. Kedua, Risk Based Capital Adalah suatu ukuran yang menginformasikan tingkat keamanan financial atau kesehatan suatu perusahaan asuransi. Ketiga, Rasio Aktiva terhadap modal sendiri Rasio ini digunakan untuk mengukur efisiensi perusahaan dalam pembelian property dan aktiva lainnya. Sedangkan beban (klaim, usaha, maupun komisi), Rasio ini merupakan perbandingan penjumlahan beban netto beban usaha dan komisi netto dengan pendapatan premi netto. Yang terakhir adalah Investasi dalam bentuk deposito Suatu bentuk investasi jangka panjang yang telah disimpan hanya boleh ditarik nasabah setelah jangka waktu tertentu.

Menurut Ketua Dewan Juri Herris Simandjuntak, tema pemeringkatan asuransi tahun 2016 adalah "Industri Asuransi pada Era Digital". Tema ini disepakati dewan juri untuk merangsang industri asuransi agar makin inovatif dalam memberikan layanan bagi para nasabahnya. "Lewat proses digitalisasi, industri asuransi diharapkan makin terpacu dalam dalam menggarap pasar dengan dukungan teknologi digital," kata Herris Simandjuntak pada penghargaan Asuransi Terbaik 2016 versi Majalah Investor, di Balai Kartini, Jakarta, Rabu

Pemeringkatan ini menggunakan 14 kriteria, baik untuk asuransi umum, asuransi jiwa, maupun reasuransi. Kriteria untuk asuransi umum pada Tabel 1:

Tabel 1. Kriteria Pemeringkatan Perusahaan Asuransi

\begin{tabular}{ll}
\hline No & Kriteria \\
\hline 1 & Pertumbuhan Aset Rata-Rata 2011-2015 \\
2 & Pertumbuhan Jumlah Investasi Rata-Rata 2011-2015 \\
3 & Pertumbuhan Ekuitas Rata-Rata 2011-2015 \\
4 & Pertumbuhan Premi Penutupan Langsung 2011-2015 \\
5 & Pertumbuhan Premi Neto Rata-Rata 2011-2015 \\
6 & Pertumbuhan Hasil Underwriting Rata-Rata 2011-2015 \\
7 & Pertumbuhan Laba Bersih Rata-Rata 2011-2015 \\
8 & Pangsa Pasar Premi Neto Tahun 2016 \\
9 & Rasio Underwriting Terhadap Premi Neto 2016 \\
10 & TATO (Total Aset Turn Over) 2016 \\
11 & ROA (return on assets) 2016 \\
12 & ROE (return on equity) 2016 \\
13 & RBC (risk based capital) 2016 \\
\hline Sumber: & wwwicraindonesia.com
\end{tabular}

Sumber: www.icraindonesia.com

\section{Metode Penelitian}

Objek yang diteliti adalah perusahaan asuransi yang telah Go Public dan terdaftar di BEI. Sebanyak sebelas perusahaan asuransi yang terdaftar di BEI. Dalam penelitian ini data yang digunakan adalah data sekunder berupa pooled data untuk semua variabel profitabilitas, RBC, rasio aktiva tetap terhadap modal sendiri, beban, dan investasi dalam bentuk deposito. Data sekunder ini diperoleh dengan metode pengamatan pada perusahaan yang terdaftar di BEI tahun 2013-2016 Alat analisis yang digunakan yaitu Microsoft excel untuk mengolah dan menganalisis data awal dan selanjutnya menggunakan Fuzzy Logic Toolbox untuk mengambil keputusan.

\section{Hasil dan Pembahasan}

Mengetahui keterkaitan antara variabel-variabel input dengan variabel-variabel output, ditunjukkan dengan rule viewer seperti pada gambar 1, dengan rule viewer seperti gambar 1 maka didapatkan bilangan real profitabiltas suatu perusahaan asuransi sebesar 0,32 berada pada kategori "besar" 
(perolehan laba cukup tinggi) dengan rata-rata pengaruhnya terhadap pendapatan premi sebesar Rp. 600.000.000.000,- sehingga profitabilitas yang dihaslkan adalah besar "artinya profitabilitas dan pendapatan premi berbanding positif. Apabila profitabilitas berada di kategori "besar" maka pendapatan premi yang dihasilkan juga akan "besar". Apabila proftabilitas lebih besar dari 0,32 maka tingkat pengembalian yang didapat perusahaan akan besar pula dan kemungkinan pendapatan premi besar. Sebaliknya apabila profitabilitas berada pada kategori "sedang " $(0,1$ sampai 0,5$)$ atau "rendah" $<0,1)$ maka profitabilitas yang dihasilkan juga "sedang" atau "kecil". Dengan demikian dapat disimpulkan bahwa profitablitas dapat mempengaruhi pendapatan premi perusahaan.

Risk based capital (RBC), didapat bilangan real RBC suatu perusahaan asuransi sebesar 0,9 berada pada kategori "cukup solven dengan rata-rata pengaruhnya terhadap pendapatan premi sebesar Rp. 600.000.000.000,- sehingga RBC yang dihasilkan adalah cukup solven "artinya profitabilitas dan pendapatan premi berbanding positif. Apabila RBC berada di kategori "cukup solven " maka pendapatan premi yang didapat perusahaan yang dihasilkan juga akan "besar". Sebaliknya apabila RBC berada pada kategori 0-0.7 maka dinyatakan tidak solven dan jika dinyatakan 1,1-1,8 dikatakan solven. Dengan demikian dapat disimpulkan bahwa risk based capital (RBC) dapat mempengaruhi sebagian besar pendapatan premi perusahaan.

Aktiva tetap terhadap modal sendiri, didapat bilangan real aktiva tetap pada modal sendiri suatu perusahaan asuransi sebesar 6 berada pada kategori memenuhi dengan rata-rata pengaruhnya terhadap pendapatan premi sebesar Rp. 600.000.000.000,- sehingga aktiva tetap terhadap modal sendiri yang dihasilkan adalah memenuhi "artinya aktiva tetap terhadap modal sendiri dan pendapatan premi berbanding negatif. Apabila $=7$ atau tidak lebih dari 7 masih dikategorikan memenuhi sedangkan $>8$ dikatakan tidak memenuhi. Dengan demikian dapat disimpulkan bahwa aktiva tetap terhadap modal sendiri dapat mempengaruhi pendapatan premi perusahaan. Beban, didapat bilangan real beban suatu perusahaan asuransi sebesar 46 berada pada kategori tidak melebihi dengan rata-rata pengaruhnya terhadap pendapatan premi sebesar Rp. 600.000.000.000,- sehingga beban yang dihasilkan adalah tidak memenuhi "artinya dan pendapatan premi berbanding negatif. Apabila $=50$ atau kurang dari 50 masih dikategorikan memenuhi sedangkan > 50 dikatakan tidak memenuhi. Dengan demikian dapat disimpulkan bahwa beban yang terdiri dari beban neto ditambah dengan komisi neto dan beban usaha dibandingkan dengan pendapatan premi dapat mempengaruhi sebagian besar pendapatan premi perusahaan.

Rule viewer seperti gambar 2 maka dapat dinyatakan didapat bilangan real profitabiltas suatu perusahaan asuransi sebesar 0.33 berada pada kategori "besar" (perolehan laba cukup tinggi) dengan ratarata pengaruhnya terhadap pendapatan premi sebesar Rp. 316.000.000.000,- sehingga profitabilitas yang dihasilkan adalah besar . Apabila profitabilitas berada di kategori "besar" maka pendapatan premi yang dihasilkan juga akan "besar". Apabila profitabilitas lebih besar dari 0.33 maka tingkat pengembalian yang didapat perusahaan akan besar pula dan kemungkinan pendapatan premi besar lebih dari Rp. 316.000.000.000,-. Sebaliknya apabila profitabilitas berada pada kategori "sedang atau lebih kecil dari Rp. 316.000.000.000,- maka profitabilitas yang dihasilkan juga "sedang" atau "kecil". Dari diatas dengan demikian dapat disimpulkan bahwa proftabiltas dapat mempengaruhi kebijakan perusahaan dalam pendapatan premi untuk sebagian perusahaan asuransi.

Risk based capital (RBC), didapat bilangan real RBC suatu perusahaan asuransi sebesar 1,08 berada pada kategori "cukup solven dengan rata-rata pengaruhnya terhadap pendapatan premi sebesar Rp. 316.000.000.000,-. Apabila RBC berada di kategori "solven" maka pendapatan premi yang didapat perusahaan yang dihasilkan juga akan "besar". Sebaliknya apabila RBC berada pada kategori "sedang atau lebih kecil dari Rp. 316.000.000.000,- maka RBC yang dihasilkan juga "sedang" atau "kecil". Dari diatas dengan demikian dapat disimpulkan bahwa RBC dapat mempengaruhi kebijakan perusahaan dalam pendapatan premi untuk sebagian perusahaan asuransi.

Rasio aktiva tetap terhadap modal sendiri, didapat bilangan real rasio aktiva tetap terhadap modal seniri suatu perusahaan asuransi sebesar 10.1 berada pada kategori memenuhi dengan rata-rata pengaruhnya terhadap pendapatan premi sebesar Rp. 316.000.000.000,-. Sehingga aktiva tetap terhadap modal sendiri yang dihasilkan adalah memenuhi "artinya aktiva tetap terhadap modal sendiri dan pendapatan premi berbanding negatif. Apabila rasio aktiva tetap lebih dari 10,1 maka pendapatan premi akan kecil. Dari diatas dengan demikian dapat disimpulkan bahwa aktiva tetap terhadap modal sendiri dapat mempengaruhi kebijakan perusahaan dalam pendapatan premi untuk sebagian perusahaan

Beban, didapat bilangan real beban suatu perusahaan asuransi sebesar 9,76 berada pada kategori memenuhi dengan rata-rata pengaruhnya terhadap pendapatan premi sebesar Rp. 316.000.000.000,sehingga beban yang dihasilkan adalah tidak memenuhi "artinya dan pendapatan premi berbanding negatif.. Jika lebih besar dari 9,76 dan pendapatan premi lebih besar dari Rp. 316.000.000.000,- maka dinyatakan tidak memenuhi namun sebaliknya apabila kuraang dari atau sama dengan 9,76 maka pendapatan premi 
lebih besar Rp. 316.000.000.000,-. Dengan demikian dapat disimpulkan bahwa beban dapat mempengaruhi kebijakan perusahaan dalam pendapatan premi untuk sebagian perusahaan asuransi

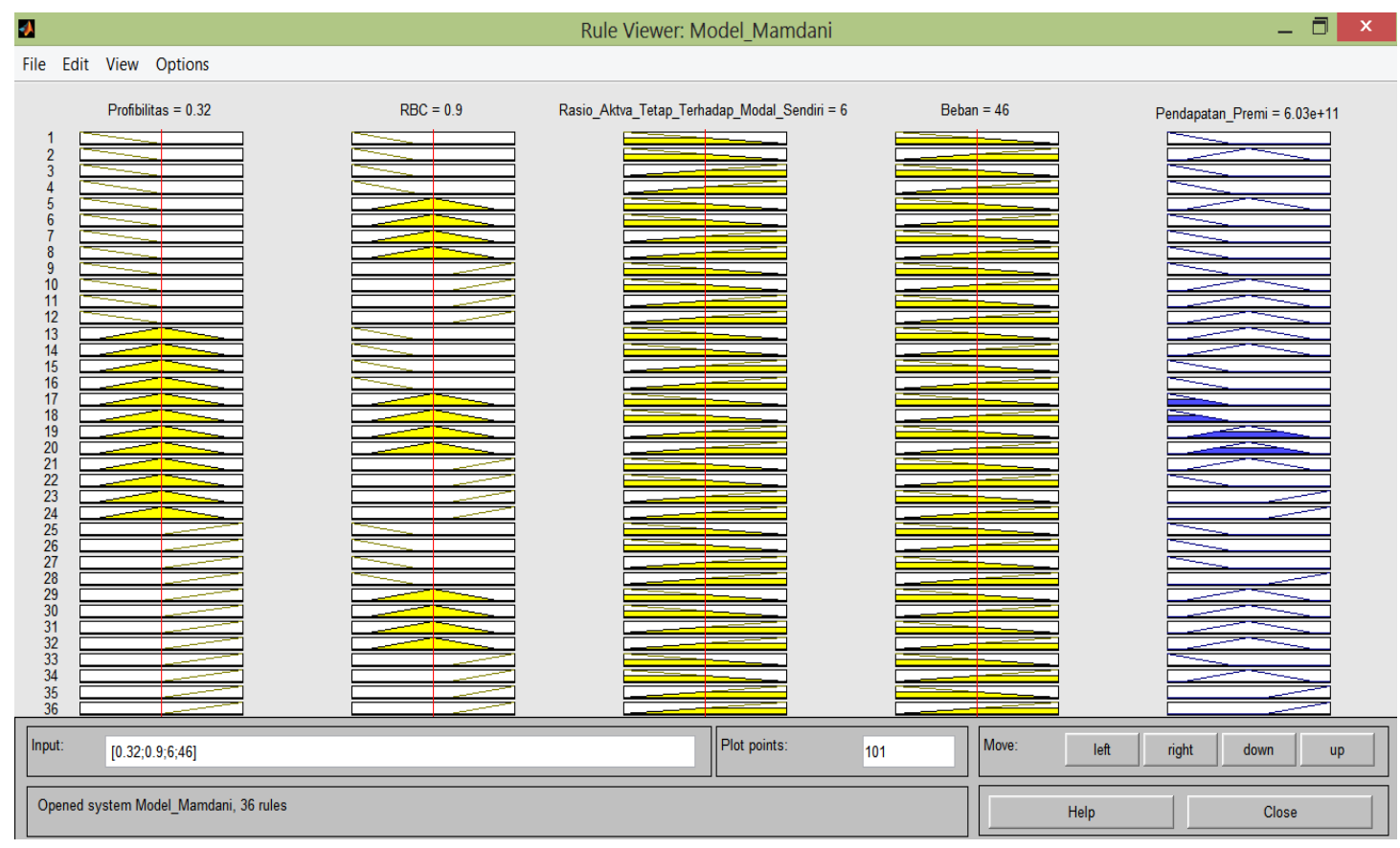

Gambar 1. Hasil Model Mamdani

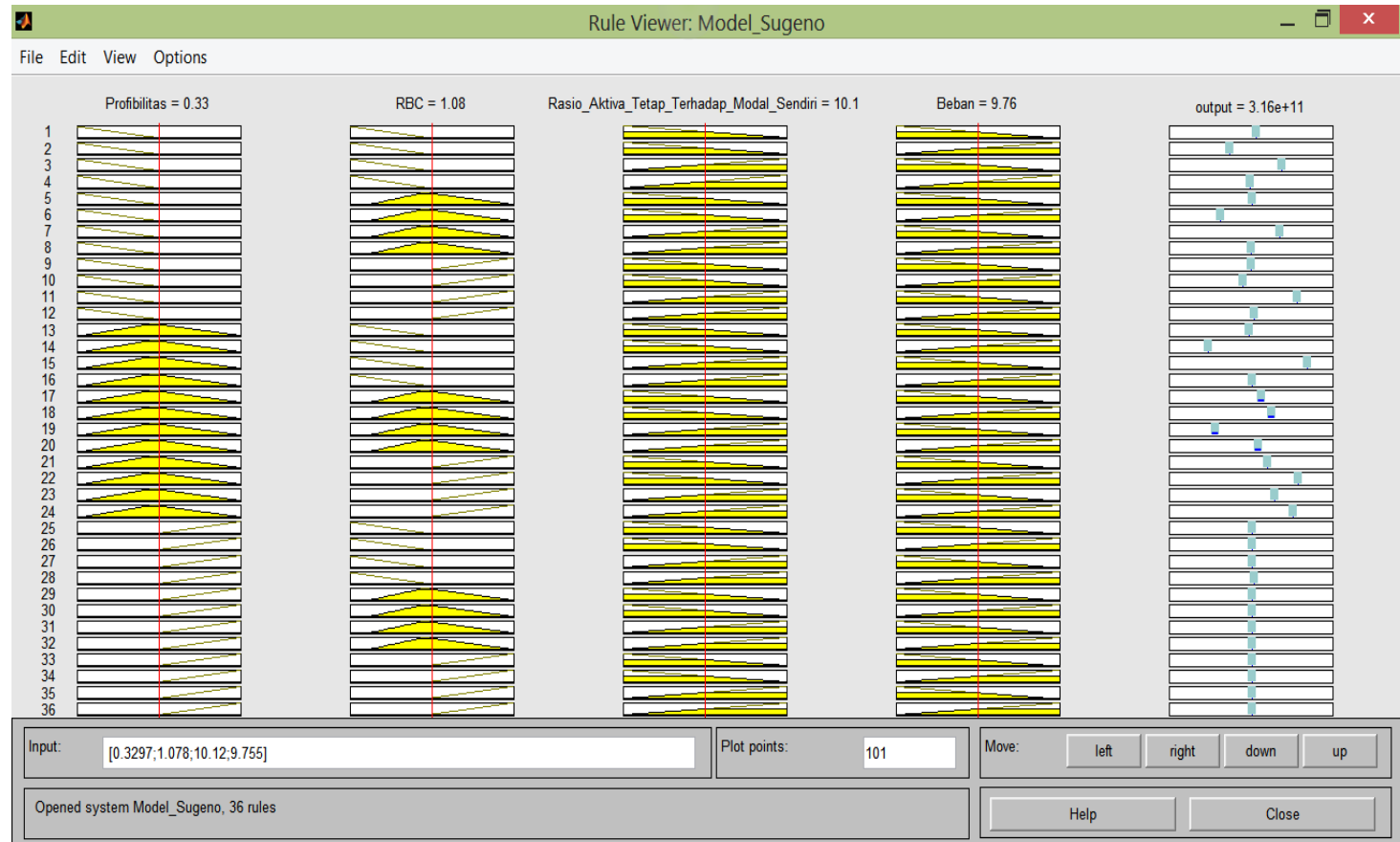

Gambar 2. Hasil Model Sugeno

\section{Kesimpulan dan Saran}

Dari penelitian yang telah diteliti Analisa Pemeringkatan Kesehatan Perusahaan Asuransi Dengan Menggunakan Pendekatan Fuzzy Logic metode mamdani dan sugeno (Study kasus perusahaan asuransi kerugian yang terdaftar di BEI periode tahun 2013-2016). Bahwa pemeringkatan asuransi 
peringkat pertama yang paling dominan / yang paling tepat dalam mengambil keputusan asuransi adalah asuransi Lippo General Insurance, kedua asuransi Maskapai Reasuransi Indonesia, ketiga Asuransi Multi Artha Guna, keempat asuransi Ramayana, kelima asuransi Harta Amana Pratama, keenam asuransi Mitra Maparya, ketujuh asuransi Jaya Tania, kedelapan asuransi Bina Dana Arta, kesembilan asuransi Dayin Mitra, dan peringkat terakhir asuransi Bintang yang mengacu pada standard tingkat kesehatan keuangan perusahaan asuransi dan perusahaan reasuransi sesuai dengan keputusan peraturan pemerintah mentri keuangan republic Indonesia pada peraturan pemerintah KMK nomor: 424/KMK.06/2003 peraturan Pemerintah republik Indonesia nomor 73 tahun 1992 tentang penyelenggaraan usaha perasuransian, majalah info bank no.340/juli 2007/vol XXIX, undang-undang nomor 2 tahun 1992 tentang peraturan usaha perasuransian. Bahwa ditemukan didalam metode mamdani dan metode sugeno ditemukan GAP antara persepsi dan harapan yang cukup signifikan antara metode mamdani dan metode sugeno.

\section{Ucapan Terima Kasih}

Tim peneliti mengucapkan terima kasih sebanyak-banyaknya kepada Pusat Pengembangan Ekonomi, Bisnis dan Kewirausahaan (PPEBK) Fakultas Ekonomi \& Bisnis Universitas Muhammadiyah Malang yang telah memberikan dukungan berupa pembiayaan penelitian ini

\section{Referensi}

Etty, Endang Nerawati. (2002). Penilaian Perusahaan Asuransi Dengan RBC dan Early Warning S y s t em, Jurusan Ekonomi Universitas Pancasila. Jakarta.Febransyah.

Ade. (2006). Mengukur Kesuksesan Produk Pada Tahap Desain; Sebuah pendekatan Fuzzy MCDM.Fakultas Teknologi Industri Universitas Prasetya Mulya Busines School, Jakarta.

Kusumadewi, Sri dan H. Purnomo. (2010). Aplikasi Logika Fuzzy Untuk Pendukung Keputusan. Graha Ilmu. Yogyakarta.

Lotfi A Zadeh. (2005). Advances in Fuzzy Mathematics and Engineering : Fuzzy Sets and Fuzzy information-granulation. Theory. Beijing: Normal University Press.

Marimin. (2005). Teori dan aplikasi sistem pakar dalam tehnologi manajerial. IPB - Press, Bogor.Prisniwi,Isty

Listyowati. (2010). Mengukur Tingkat Konsentrasi Pasar Dalam Struktur Industri Asuransi Kendaraan Bermotor terhadap perolehanPendapatan Premi Netto pada Asuransi Kerugian.Fakultas Ekonomi Universitas Indonesia. Jakarta.

Sri Kusumadewi, (2002). Analisis dan Desain Sistem Fuzzy menggunakan Tool Box Matlab, edisi pertama. Penerbit Graha Ilmu, Jakarta.

Silvia, Sischa, christien. (2010). Penentuan Kebijakan Deviden Dengan Menggunakan Fuzzy Logic Study Kasus Perusahaan Perbankan. Tesis Program Pasca Sarjana Magister Manajemen Perbankan Universitas Gunadarma. Jakarta.

Wulan, Novie. (2002). Pengaruh RBC Terhadap Tingkat Profitabilitas Pada PT.Asuransi Bina Dana Arta Tbk. Unikom.http://www.investor.co.id/home/delapan-perusahaan-raih-asuransi-terbaik2013-versi-majalah-investor/64102. Pemeringkatan Asuransi. Diunduh Pada Nopember 2016.

The Math Works. 2002. Fuzzy Logic Toolbox User Guide, The Math Works,Inc.

The Math Works.2005. Getting Started With MATLAB, The math Works,Inc

Tim Studi Bapepam LK.2008. Permodalan Asing Perusahaan Perasuransian 
